\title{
STUDYING THE PROPERTIES OF CONSTRUCTED WETLAND SEDIMENTS FOR THEIR POSSIBLE APPLICATION AS FERTILIZERS
}

\author{
Yuriy Vergeles ${ }^{I}$ \\ Nataliya Butenko \\ Andriy Ishchenko ${ }^{I}$ \\ Lidiya Svirenko ${ }^{l}$ \\ Felix Stolberg ${ }^{I}$ \\ William Hogland ${ }^{2}$ \\ ${ }^{\prime}$ National Academy of Municipal Economy, Ukraine \\ ${ }^{2}$ University of Kalmar
}

\begin{abstract}
The processes of sediment formation and their biogeochemical properties were studied in 2005-2007 at the experimental constructed wetland site ("Bioplato") designed for treatment of domestic effluents in Ukraine, nearby the city of Kharkiv. The constructed wetland consists of three units: one with vertical filtration applying fine gravel $(0.5 \mathrm{~m}$ in depth $)$ and coarse sand $(0.3 \mathrm{~m})$ as filtering media, one with horizontal filtration applying middle sand $(0.8 \mathrm{~m})$ as a filtering medium, and one surface flow unit with natural wetland soil applied. The site also includes a septic tank and a small sludge-drying field. The constructed wetland with a capacity of $50 \mathrm{~m}^{3}$ of treated domestic wastewater per day was established in 1998 and since then it has been operated continuously until now. Macrophytes were planted in 1998-2001, and recently the reed (Phragmites australis), cattail (Typha latifolia), and a number of sedge species (Carex spp.) dominate over the rest of ca. 30 plant species with average cover of 85 $90 \%$. Treatment efficiency of $90-95 \%$ of $\mathrm{BOD}_{5}$ and suspended solids removal, as well as 98 $99 \%$ of removal of pathogenic microorganisms allows discharging the treated wastewater into adjacent artificial lake. Sludge was sampled at each unit followed with standard laboratory analyses of its main characteristics: total organic carbon (TOC), total nutrients (N, P), contents of trace elements, abundance of pathogenic microorganisms, and general toxicity. The results of analyses confirmed that the top layer of sludge from each unit of the assessed constructed wetland site could be used as a source of fertilizers for grain and leguminous crops.
\end{abstract}

\section{KEYWORDS}

Sediments; TOC; Nutrients; Constructed wetlands; Ukraine.

\section{INTRODUCTION}

For almost three decades constructed wetlands have been extensively applied worldwide as an effective low-cost ecological technology for secondary, tertiary and, in some cases the only 
treatment of domestic and certain kinds of industrial wastewater, agricultural and urban runoff, as well as for purification and protection against pollution of natural waters $[5,12,16$, $18,19,26,27,29,30,33]$. Among different types of constructed wetlands the vertical and horizontal filtration (subsurface) systems and free surface wetlands are applied the most often for the above mentioned purposes [1, 2, 6, 12, 19, 26, 28, 33]. All such systems consist of mineral substrate where aquatic helophyte and hydrophyte vegetation are established to provide the media for associated roots and rhizomes microorganisms and to serve as a complex natural "device" utilizing nutrients, accumulating metals and decomposing other pollutants. Processes of sedimentation, filtration, decomposition, accumulation and nutrient cycling take place simultaneously in the constructed wetlands, thus proving their general efficiency and feasibility.

To date, great amount of data is collected on constructed wetlands biotic components' ability to reduce significantly contents of pollutants (COD, BOD, suspended solids, nutrients, metals, synthetic compounds, oil products, etc.) and pathogens in the treated wastewater $[1,3,4,5,6$, $7,14,15,17,18,19,29,32,34]$. Less known are processes of sediment formation and properties in the constructed wetland systems featuring mineral and organic-mineral substrates as filtering media. Such knowledge is necessary when restoration or reestablishment of artificial wetland systems is planned after their maturation/ageing accompanied with clogging and reduction of overall efficiency $[8,28,30,31]$. In those cases when removal of sediments is foreseen it is important to understand their chemical, toxicological and sanitary (bacteriological and parasitological) characteristics in order to identify the future possible ways of sediments utilisation and/or minimising their negative impacts on the environment. In the most of relevant literature a critical age of artificial wetland systems, after which restoration or regeneration would be desirable, is suggested as 7 to 10 years.

This article summarises preliminary investigations of the properties of sediments at an experimental constructed wetland system that has been established and used as the only mean for purification of domestic wastewater from a small village in Ukraine for nine years.

Research questions were defined as the following:

- How sedimentation processes in the constructed wetlands with vertical and horizontal filtration in temperate climates effect mechanical composition of the filtering medium at the wetland's maturation?

- What is mechanical composition of sediment layer of the free-surface constructed wetland after continuous exploitation and maintenance for several years without regeneration?

- How much organic matter and nutrients are contained in constructed wetland sediments?

- What are patterns of metal accumulation in sediments?

- What are bacteriological and parasitological characteristics of sediments?

- Do chemical, toxicological and sanitary characteristics of investigated sediments allow their potential application in agriculture if the sediments would be removed during reconstruction/regeneration of the constructed wetland site?

Field data were collected and results of laboratory analyses of sampled sediments were made during 2005-2007 and used for answering the above questions. 


\section{METHODS}

\subsection{Experimental constructed wetland site}

For the purposes of this study the constructed wetland at the Velyki Prokhody village, Dergachi district, Kharkiv Oblast (region), Ukraine was used as an experimental site (Figure 1).

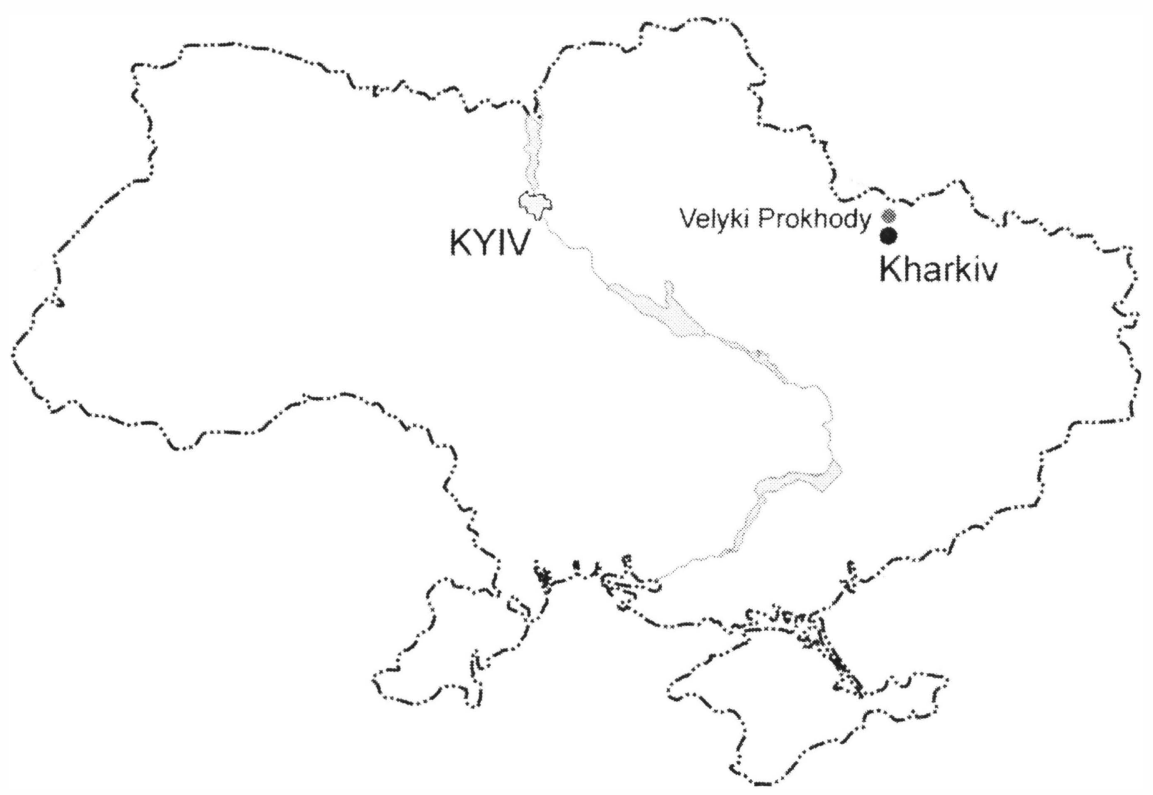

Figure 1. Location of the experimental constructed wetland site: the Velyki Prokhody village, Kharkiv Oblast (region), Ukraine.

Known as the "Bioplato", the artificial wetland receiving up to $50 \mathrm{~m}^{3}$ of domestic wastewater per day was designed in 1997 and put into operation in May 1998 in the frames of the EU INCO-COPERNICUS Project ${ }^{5}[27]$. The constructed wetland consists of three units, a sedimentation tank before the first unit, and the patch of natural cattail and sedge vegetation in the gully, where wastewater outflows to after treatment (Figure 2.) Units 1 and 2 are vertical and horizontal flow constructed wetlands. At the first unit gravel $(0.5 \mathrm{~m}$ in depth $)$ and coarse sand $(0.3 \mathrm{~m})$ were applied and at the second unit a $0.8 \mathrm{~m}$-thick coarse and middle sand as filters. Both units are supplied with drainage pipes. The third unit is a free surface system, where natural soil filter together with planted macrophytes is used. Distributive pipe system is designed in such way as to provide both autonomic and joint operation of three units. Each

${ }^{5}$ Research and information on water purification by means of constructed wetlands (Bioplatos) in Ukraine, supported by studies in Estonia, Finland, the Netherlands and Sweden, financed by EU/INCO-DC Program (Co-operation with the third countries and international organizations, Part C, contract $\mathrm{N}^{\circ}$ ERBIC 15CT960100) 
unit has separate outlet to the gully. The outlet from the third unit is used as general outlet while wastewater runs consequently through the first to the third treatment units. Each unit is insulated with polymer film in order to prevent infiltration to groundwater. To supply development of macrophytes, rhizomes of the six most frequent local species - Reed Phragmites communis, Cattail Typha latifolia, Wood Bulrush Scirpus sylvaticus, Sedges Carex acuta, C. nigra, C. hirta - were taken from natural wetland below the lake and placed on the third unit's surface together with wet soil in late May - early June 1998. The reeds and cattails were planted on unit 2 in July 1998 and July 1999. On unit 1, macrophytes were planted in 2000-2001. Recently, these species dominate over the rest of ca. 30 plant species with average total cover of $85-90 \%$.

For the whole period of wetland's operation since 1998, the units featured high efficiency in pollutant removal as certified with the results of water quality control measurements done by the Kharkiv Regional Sanitary and Epidemiological Authority. Thus, treatment efficiency was $90-95 \%$ for $\mathrm{BOD}_{5}$ and $90-97 \%$ for suspended solids removal, as well as $98-99 \%$ of removal of pathogenic microorganisms (Table l). Wastewater after treatment satisfies the requirements of national regulations and therefore is discharged into adjacent artificial lake.

Table 1. Average indexes of quality of domestic wastewater treated at the Velyki Prokhody constructed wetland site, Ukraine, and the pollutant removal efficiency.

\begin{tabular}{l|ccc}
\hline Index & Average concentrations, $m g / l(1998-2007)$ & $\begin{array}{c}\text { Average removal } \\
\text { efficiency, } \%\end{array}$ \\
\cline { 2 - 3 } Suspended solids & Inlet & Outlet & 96.37 \\
$\mathrm{COD}$ & 321.89 & 11.70 & 81.95 \\
$\mathrm{BOD}_{5}$ & 209.15 & 37.75 & 93.11 \\
$\mathrm{NH}_{4}-\mathrm{N}$ & 77.68 & 5.35 & 48.09 \\
$\mathrm{~N}$ total & 54.60 & 28.34 & 29.05 \\
$\mathrm{P}$ total & 2.73 & 1.94 & 30.58 \\
Laundry detergents & 6.38 & 4.43 & 76.56 \\
Faecal Coli-forms, & 0.337 & 0.079 & 99.13 \\
$\mathrm{x} 10^{5}, 1^{-1}$ & 9133 & 22.3 & \\
Coli-phages, & & & 98.15 \\
$\mathrm{x} 10^{3}, \mathrm{l}^{-1}$ & 2619 & 6.5 & \\
\hline
\end{tabular}




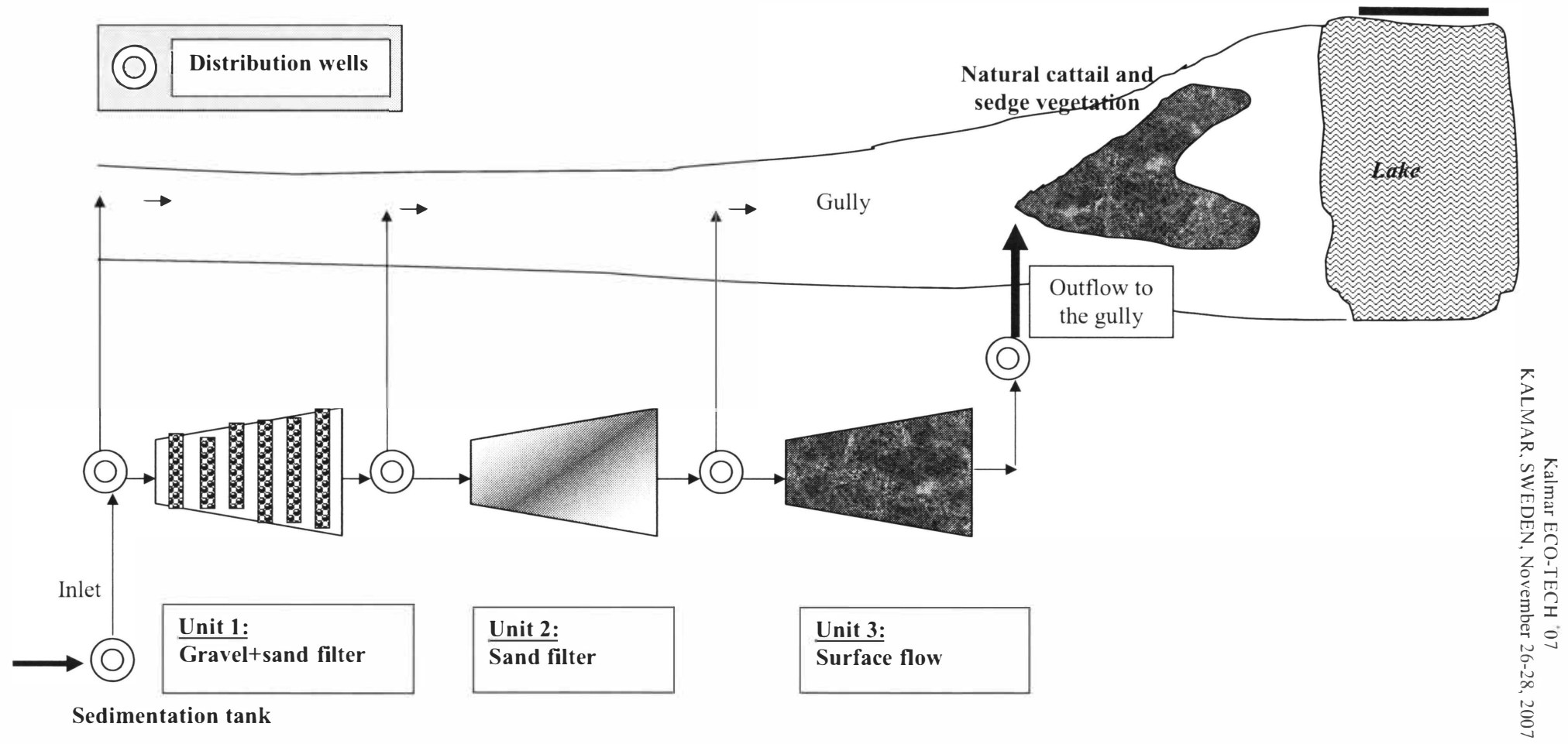

Figure 2. Sketch of the experimental constructed wetland site for domestic w'astewater treatment ("Bioplato") at the Velyki Prokhody village. 
Average figures of pollutants removal suggest that there was no significant reduction in efficiency of the Velyki Prokhody constructed wetland over 9 years of continuous operation.

\subsection{Sampling design}

A stratified random sampling design was applied to the study. Sediments were sampled in May 2006 at each unit of the experimental constructed wetland site, from sedimentation tank and from the lake at the dam. At each sampling point but the unit 1 , sediments were collected from two strata $-0-5 \mathrm{~cm}$ and $20-30 \mathrm{~cm}$ below the bottom's surface. At the unit 1 water depth did not allow to do so at the moment, and samples were taken from the upper stratum only. Total number of samples was 21 .

Constructed wetland and lake sediments were composed of mineral filtering substrate, solid particles settled from the wastewater during sedimentation, products of wastewater organic matter decomposition, plant residuals and products of their decomposition, as well. Before laboratory analyses of sediments all vegetation residuals were removed from the samples.

Collection, preservation and handling of samples were done according to international standards $[8,9,10]$.

\subsection{Laboratory analyses of samples}

Mechanical composition and particles' density of sampled sediments were measured by the gravimetric technique at the Environmental Analytical Laboratory of the National Academy of Municipal Economy Kharkiv.

Measurements of total organic carbon, total nitrogen, phosphorus and $\mathrm{pH}$ of water extract of sediments were done at the Chemical Analytical Laboratory of the Ukrainian Research and Design Institute of Water Supply, Sewerage Systems and Environmental Engineering "UkrVodGeo", Kharkiv, with application of standard techniques [21, 22, 23, 24].

Sanitary bacteriological and parasitological properties of sediments were studied with application of standard detection techniques at the Analytical Laboratory of Kharkiv Regional Sanitary and Epidemiological Authority [25].

The contents of 9 metal elements in sediment samples were measured by emission spectroscopy techniques (DS259/SM3120ICP for $\mathrm{Fe}, \mathrm{Cd}, \mathrm{Cr}, \mathrm{Cu}, \mathrm{Ni}, \mathrm{Sr}, \mathrm{Zn}$; SM3113HGAAS for Ag and Sn) at the Eurofins Sverige AB, Sweden.

Results of the laboratory analyses are presented in Figure 3 and Tables $2-4$.

\section{RESULTS AND DISCUSSION}

\subsection{Mechanical composition and $\mathrm{pH}$ of substrate at different constructed wetland units}

Sediments in the sedimentation tank and constructed wetland units differed by their mechanical composition (grain-size distribution) and degree of heterogeneity (Figure 3). In the sedimentary tank coarse and middle sand particles were accumulated with heterogeneity coefficient of 6.7. In the constructed wetland units with vertical and horizontal filtration fine sand fraction was the best represented, and coefficient of sediment heterogeneity was 1.8 to 3.8. In the third unit sediments featured fine and middle sand fractions with coefficient of heterogeneity of 6.4 that makes them similar to the sand filter. This can be explained by the 
presence of middle and fine sand substrate at the unit provided for drainage upon which the soil and rhizome layer was established. Here sediment particles' density was $2.51-2.52 \mathrm{~g} / \mathrm{cm}^{3}$, and the sand's density (from drainage substrate) $-2.66 \mathrm{~g} / \mathrm{cm}^{3}$.

Mechanical composition of sediments from adjacent lake is quite typical for water bodies of such kind.

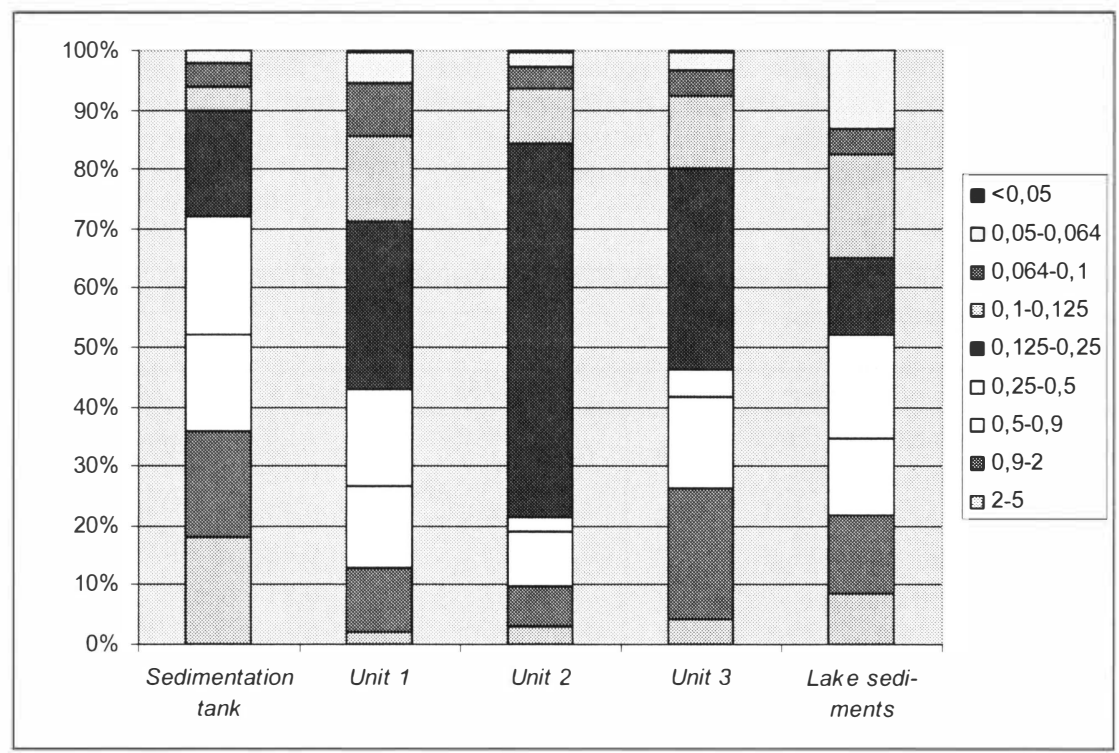

Figure 3. Mechanical composition of sediments of the Velyki Prokhody constructed wetland site (figures in the legend are attributed to fractions with different grain size, $\mathrm{mm}$ ).

Measured $\mathrm{pH}$ of water extract from sediments at each unit (6.8-7.2) showed their neutral properties.

\subsection{Total organic carbon and nutrient contents of sediments}

Sediments from investigated constructed wetland contained organic matter and nutrients in concentrations less or almost equal to those of artificial lake (Table 2). The highest total organic carbon's (TOC) contents were found in the upper strata of sediments from the sedimentation tank and unit 1 . Significantly less amounts of TOC were found in the sediments of units 2 and 3 that may suggest more extensive processes of organic matter decomposition comparing to previous stages of wastewater treatment. Although TOC contents of sediments at all sampling points were much less than those required for organic fertilizers, this measured index appeared very similar to average TOC contents in typical chernozem soils of the region [13]. 
lower in constructed wetland sediments than in the lake excepting nitrogen in sediments from the septic tank where its concentration was the highest. Total phosphorus content in tank's sediments was several times higher than in wetland's sediments but still slightly less than in the lake. There is clear trend of increasing phosphorus availability in sediments from the first unit with vertical filtration wetland through the second unit with horizontal filtration wetland to the third unit with free surface wetland. For total nitrogen, although its content was the highest in sediments of the third unit comparing to the first two, differences among units were rather insignificant. By nutrients contents, constructed wetland sediments are much richer than typical chernozem soils of the region, and just slightly differ to the less from requirements stated in the standards for organic fertilizers. However, sludge from the sedimentation tank has greater potential for the use as a fertilizer since nutrients contents in it is significantly higher than minimum requirements.

Table 2. Average nutrient contents of sediments (upper strata, 0-5 cm) of the Velyki Prokhody constructed wetlands, Ukraine.

\begin{tabular}{c|ccc}
\hline Sampling point & TOC, \% & Total N, \% & Total P, \% \\
\hline Sedimentation tank & 2.94 & 1.08 & 1.03 \\
Unit 1 $(\mathrm{n}=3)$ & 3.01 & 0.42 & 0.193 \\
Unit 2 $(\mathrm{n}=4)$ & 2.07 & 0.37 & 0.485 \\
Unit 3 $(\mathrm{n}=3)$ & 2.24 & 0.48 & 0.546 \\
Artificial lake & 2.72 & 0.81 & 1.15 \\
& 20 & 0.60 & 0.645 \\
Standard requirements [20] & & & \\
Contents in typical soils of the region & 2.5-4.6 (humus) & $0.14-0.30$ & $0.123-0.178$ \\
[13] & & & \\
\hline
\end{tabular}

Sediments sampled from deeper sand-containing strata at constructed wetland units 2 and 3 featured much lower contents of organic matter and nutrients: $0.059 \%, 0.255 \%$ and $0.035 \%$ for TOC, total nitrogen and total phosphorus, respectively.

\subsection{Metal contents of sediments}

Contents of all studied metal elements and arsenic in all sampled sediments were less than limits permitted by standards for organic fertilizers; however these were generally several times higher than background contents in typical soils of the region (Table 3).

Although detailed discussion on patterns of metal and arsenic accumulation in sediments of constructed wetlands of different types compared to patterns of the same elements accumulation and speciation in plants of the associated vegetation will be the subject of another paper, some preliminary observations can be made.

The iron was greater accumulated by sediments of the sedimentation tank and the top stratum at the third unit than in other cases. Cadmium's concentrations in sediments were the highest in deeper strata at the second and third units. For copper, nickel and chromium the pattern is that highest concentrations were found in the sediments of unit 3 comparing to other sites. 
Two later elements also showed significantly higher concentrations in deeper comparing to upper sediments' strata. For strontium, the highest and similar contents were found in sediments of the sedimentation tank and unit 3 , and in sediments of other wetland units it had much less contents. The highest in the series concentration of arsenic was observed for sediments of the first unit, with further strong trend of reduction to almost background concentrations at the subsequent wetland units. The highest content of zinc was observed in sediments of the sedimentation tank with further reduction up to 11 times towards the third unit. Lead was the only element with the contents less than the background concentration at each stage of wastewater treatment, however clear pattern of its distribution in the sampled sediments was not revealed.

Table 3. Average contents of heavy metals, mg/kg, in sediments of the Velyki Prokhody constructed wetland site, Ukraine.

\begin{tabular}{|c|c|c|c|c|c|c|c|c|c|}
\hline Sampling point & $C d$ & $C u$ & $\mathrm{Ni}$ & $\mathrm{Pb}$ & $\mathrm{Cr}$ & $Z n$ & $A s$ & $\mathrm{Sr}$ & $\mathrm{Fe}$ \\
\hline $\begin{array}{l}\text { Inlet } \\
\text { (wastewater) } \\
\mathrm{mg} / \mathrm{l}\end{array}$ & 0.13 & 5.6 & 9.2 & 5.8 & 5.3 & 121.0 & 2.4 & -6 & 1480 \\
\hline $\begin{array}{l}\text { Sedimentation } \\
\text { tank }\end{array}$ & 1.80 & 22.0 & 70.0 & 4.0 & 60.0 & 550.0 & 0.7 & 263.0 & 48000 \\
\hline Unit $1(n=3)$ & 1.87 & 31.7 & 38.3 & 8.3 & 58.3 & 108.3 & 5.3 & 145.0 & 24933 \\
\hline $\begin{array}{l}\text { Unit } 2 \text { (depth } 0 \text { - } \\
5 \mathrm{~cm}, \mathrm{n}=4 \text { ) }\end{array}$ & 1.05 & 30.8 & 58.5 & 10.0 & 33.8 & 61.0 & 3.5 & 84.0 & 12100 \\
\hline $\begin{array}{l}\text { Unit } 2 \text { (depth } \\
20-30 \mathrm{~cm}, \mathrm{n}=4)\end{array}$ & 3.60 & 70.0 & 117.0 & 8.5 & 82.5 & 65.0 & 0.8 & 44.5 & 9500 \\
\hline $\begin{array}{l}\text { Unit } 3 \text { (depth } 0- \\
5 \mathrm{~cm}, \mathrm{n}=3 \text { ) }\end{array}$ & 1.10 & 105.0 & 105.0 & 9.0 & 80.0 & 47.5 & 1.0 & 213.0 & 44750 \\
\hline $\begin{array}{l}\text { Unit } 3 \text { (depth } \\
20-30 \mathrm{~cm}, \mathrm{n}=3 \text { ) }\end{array}$ & 1.90 & 90.0 & 120.0 & 5.0 & 120.0 & 20.0 & 1.0 & 273.0 & 32000 \\
\hline $\begin{array}{l}\text { Background } \\
\text { concentrations } \\
\text { in the regional } \\
\text { soils [13] }\end{array}$ & 0.50 & 27.0 & 38.0 & 20.0 & 70.0 & 70.0 & 1.7 & 100.0 & 14000 \\
\hline $\begin{array}{l}\text { Permitted upper } \\
\text { limits [20] }\end{array}$ & $\begin{array}{c}300 . \\
00\end{array}$ & 1500.0 & 400.0 & 500.0 & 1000.0 & 3500.0 & 20.0 & $\mathrm{n} / \mathrm{a}$ & $\mathrm{n} / \mathrm{a}$ \\
\hline
\end{tabular}

\subsection{Sanitary bacteriological and parasitological properties of wetland sediments}

Data on sanitary and epidemiological characteristics of sampled sediments suggest that only sediments from the unit 3 and the lake conform to the standard requirements set up for organic fertilizers (Table 4). By the contents of faecal coli-forms, sediments from the sedimentation tank and units 1 and 2 do not suit the standards [25], and disinfection (through e.g. thermal treatment) should precede their possible application as fertilizers.

\footnotetext{
${ }^{6} \mathrm{~W}$ as not measured
} 
No eggs of helminthes, cysts of pathogenic protozoans and pathogenic bacteria like Salmonella and Schigella were found in sampled sediments.

Taking into account the fact the experimental constructed wetland site was designed as a chain of different units to form the whole and comparing outflow to inflow concentrations of faecal coli-forms we can conclude that investigated constructed wetland system is highly effective and efficient mean of wastewater disinfection.

Table 4. Sanitary, bacteriological and parasitological characteristics of sediments of the Velyki Prokhody constructed wetland site, Ukraine

\begin{tabular}{|c|c|c|c|c|c|c|}
\hline Index & $\begin{array}{l}\text { Sedimen- } \\
\text { tation } \\
\text { tank }\end{array}$ & Unit l & Unit 2 & Unit 3 & $\begin{array}{l}\text { Lake } \\
\text { sedi- } \\
\text { ments }\end{array}$ & $\begin{array}{l}\text { Standard } \\
\text { requirements } \\
\text { for the } \\
\text { sediments of } \\
\text { the I and II } \\
\text { groups }\end{array}$ \\
\hline $\begin{array}{l}\text { Faecal Coli- } \\
\text { forms, cells/g } \\
\text { of wet } \\
\text { sediments }\end{array}$ & $1 * 10^{7}$ & $1 * 10^{7}$ & $1 * 10^{6}$ & 1000 & 1000 & $100-1000$ \\
\hline $\begin{array}{l}\text { Pathogenic } \\
\text { microorganisms } \\
\text { incl. } \\
\text { Salmonella, } \\
\text { cells/g }\end{array}$ & not found & $\begin{array}{l}\text { not } \\
\text { found }\end{array}$ & $\begin{array}{l}\text { not } \\
\text { found }\end{array}$ & $\begin{array}{l}\text { not } \\
\text { found }\end{array}$ & $\begin{array}{l}\text { not } \\
\text { found }\end{array}$ & absence \\
\hline $\begin{array}{l}\text { Helminthes' } \\
\text { eggs and } \\
\text { pathogenic } \\
\text { protozoans' } \\
\text { cysts, } \mathrm{kg}^{-1} \text { of } \\
\text { wet sediments }\end{array}$ & not found & $\begin{array}{l}\text { not } \\
\text { found }\end{array}$ & $\begin{array}{l}\text { not } \\
\text { found }\end{array}$ & $\begin{array}{l}\text { not } \\
\text { found }\end{array}$ & $\begin{array}{l}\text { not } \\
\text { found }\end{array}$ & absence \\
\hline
\end{tabular}

\section{CONCLUSIONS}

Based on results of our study we can conclude that sediments accumulated in constructed wetlands of different types by their chemical, toxicological and sanitary properties are generally suitable for small-scale applications as fertilizers for grain and leguminous crops in cases when sediments should be removed. However, layer of sediments in small constructed wetlands (receiving up to $100 \mathrm{me}^{3}$ of wastewater per day) is often very thin $(\mathrm{ca} .10 \mathrm{~cm})$ that makes practically difficult its separation from the filtering substrates.

Mechanical composition of constructed wetland sediments is determined by both the composition of filtering media and suspended solids contents and peculiarities of their sedimentation from the wastewater. Sedimentation processes in constructed wetlands with vertical and horizontal filtration and well-established macrophyte vegetation do not obviously lead to the clogging of the filtering substrates. 
Continuous exploitation of constructed wetland treatment systems with stationary or quasistationary technological parameters for long time is not obviously associated with reduction in treatment effectiveness and efficiency after 7-10 years of operation. Although there are general recommendations to restore/re-generate constructed wetlands' ability to remove pollutants with this periodicity, we can say that period of continuous operation may be much longer, and the needs for reconstruction/re-generation should be identified based on actual performance of constructed wetlands.

\section{ACKNOWLEDGEMENTS}

Authors acknowledge support from the Visby Programme (Sweden) in 2005-2006 for collection and analyses of data used in this paper.

\section{REFERENCES}

[1] Akratos Ch. S., Tsihrintzis V. A., 2007. Effect of temperature, HRT, vegetation and porous media on removal efficiency of pilot-scale horizontal subsurface flow constructed wetlands. Ecol. Engin., 29(2), 173-191.

[2] Álvarez J. A., Bécares E., 2006. Seasonal decomposition of Typha latifolia in a freewater surface constructed wetland. Ecol. Engin., 28(4), 173-191.

[3] Braskerud B. C., 2002. Factors affecting nitrogen retention in small constructed wetlands treating agricultural non-point source pollution. Ecol. Engin., 18(3), 351-370.

[4] Braskerud B. C., 2002. Factors affecting phosphorus retention in small constructed wetlands treating agricultural non-point source pollution. Ecol. Engin., 19(1), 41-61.

[5] Brix H, 1994. Constructed wetlands for municipal waster water treatment in Europe. In: Global Wetlands: Old World and New /Mitsch W.J., ed. Elsevier Science B.V., Dorderecht, pp. 325-333.

[6] Gschlößl T., Stuibe H., 2000. Reed bed systems: Design, performance and maintainability. Wat. Sci. Tech., 41(1), 73-76.

[7] Hafner S. D., Jewell W. J., 2006. Predicting nitrogen and phosphorus removal in wetlands due to detritus accumulation: A simple mechanistic model. Ecol. Engin., 27(1), 13-21.

[8] Havens K. J., Varnell L. M., Watts B. D., 2002. Maturation of a constructed tidal marsh relative to two natural reference tidal marshes over 12 years. Ecol. Engin., 18(3), 305315 .

[9] International Standard ISO 5667-13: 1994 (E), 1994. 2nd ed. - Water quality. Sampling. - Part 13: Guidance on the sampling of sewage, waterworks and related sludges. International Standard Organisation, Geneve.

[10] International Standard ISO 5667-3: 1994 (E), 1994. 2nd ed. - Water quality. Sampling. - Part 3: Guidance on the preservation and handling of samples. International Standard Organisation, Geneve.

[11] International Standard ISO 5667-8: 1994 (E), 1994. 2nd ed. - Water quality. Sampling. - Part 8: Guidance on the sampling of wet deposition. International Standard Organisation, Geneve.

[12] Kadlec R. H., 2006. Free surface wetlands for phosphorus removal: The position of the Everglades Nutrient Removal Project. Ecol. Engin., 27(4), 361-379.

[13] Krupski N. K., Polupan N. I.,eds., 1979. Atlas pochv Ukrainskoy SSR (Soil Atlas of the Ukrainian SSR). Urozhay Publ., Kiev (in Russian) 
[14] Kvarnström E. M., Morel Ch. A. L., Krogstad T., 2004. Plant-availability of phosphorus in filter substrates derived from small-scale wastewater treatment system. Ecol. Engin., 22(1), 1-15.

[15] Li W., Recknagel F., 2006. Balancing phosphorus adsorption and consumption processes in experimental treatment ponds for agricultural drainage water. Ecol. Engin., 28(1), 14-24.

[16] Maine M. A., Suñe N., Hadad H., Sánchez G., Bonetto C., 2006. Nutrient and metal removal in a constructed wetland for wastewater treatment from metallurgic industry. Ecol. Engin., 26(4), 341-347.

[17] Nguyen L., Sukias J., 2002. Phosphorus fractions and retention in drainage ditch sediments receiving surface runoff and subsurface drainage from agricultural catchments in the North Island, New Zealand. Agriculture, Ecosystems \& Environment, 92(1), 49-69.

[18] Sakadevan K., Bavor H. J., 1999. Nutrient removal mechanisms in constructed wetlands and sustainable water management. Wat. Sci. Tech., 40(2), 121-128.

[19] Scholz M., Xu J., 2002. Comparison of constructed reed beds with different filter media and macrophytes treating urban stream water contaminated with lead and copper. Ecol. Engin., 18(3), 385-390.

[20] State Standard GOST 17.4.3.04-85, 1985. Okhrana prirody. Pochvy. Obshchiye trebovaniya k kontrolyu i okhrane ot zagryazneniya. (Environmental protection. Soils. General requirements on the control and protection against pollution). State Standardization and Metrology Committee, Moscow (in Russian).

[21] State Standard GOST 26213-91, 1991. Pochvy. Metody opredeleniya organicheskogo veshchestva. (Soils. Methods of measurements of organic matter's contents). State Standardization and Metrology Committee, Moscow (in Russian).

[22] State Standard GOST 26714-85, 1985. Udobreniya organicheskiye. Metody opredeleniya zoly. (Organic fertilizers. Methods of measurements of ash). State Standardization and Metrology Committee, Moscow (in Russian).

[23] State Standard GOST 26715-85, 1985. Udobreniya organicheskiye. Metody opredeleniya obshchego azota. (Organic fertilizers. Methods of measurements of total nitrogen). State Standardization and Metrology Committee, Moscow (in Russian).

[24] State Standard GOST 26717-85, 1985. Udobreniya organicheskiye. Metody opredeleniya obshchego fosfora. (Organic fertilizers. Methods of measurements of total phosphorus). State Standardization and Metrology Committee, Moscow (in Russian).

[25] State Standard GOST R 17.4.3.07- 2001, 2001. Okhrana prirody. Pochvy. Trebovaniya k svoystvam osadkov stochnykh vod pri ispol'zovanii ikh $\mathrm{v}$ kachestve udobreniy. (Environmental protection. Soils. Requirements on the properties of sewage sludge for their application as fertilizers). State Standardization and Metrology Committee, Moscow (in Russian).

[26] Steer D., Fraser L., Boddy J., Seiberth B., 2002. Efficiency of small constructed wetlands for subsurface treatment of single-family domestic effluent. Ecol. Engin., 18(4), 429-440.

[27] Stolberg, F. V., Vergeles, Yu. I., Ladyzhenski, V. N., Ihme, R., Sevola P., Wallsten, M., and Pieterse, A., 1999. Implementation of artificial wetland technology for wastewater purification in the Ukraine: Preliminary results of a pilot project and perspectives for wide scale application. Proceedings of the 4th International Conference "Managing the Wastewater Resource: Ecological Engineering for Wastewater Treatment" /B. Kløve, C. Etnier, P. Jenssen and T. Mæhlum, eds. The Agricultural University of Norway, Ås, pp. III/1-III/6. 
[28] Suliman F., French H. K., Haugen L. E., Sovik A. K., 2006. Change in flow and transport patterns in horizontal subsurface flow constructed wetlands as a result of biological growth. Ecol. Engin., 27(2), 124-133.

[29] Söderqvist T., 2002. Constructed wetlands as nitrogen sinks in southern Sweden: An empirical analysis of cost determinants. Ecol. Engin., 19(2), 161-173.

[30] Vandaele S., Thoeye C., Van Eygen B., De Gueldre G., 2000. Reed bed systems: design, performance and maintainability. Wat. Sci. Tech.e 41(1), 57-63.

[31] Wang H., Jawitz J. W., White J. R., Martinez CH. J., Sees M. D., 2006. Rejuvenating the largest municipal treatment wetland in Florida. Ecol. Engin.e 26(2), 132-146.

[32] Werker A. G., Dougherty J. M., McHenry J. L., Van Loon W. A., 2002. Treatment variability for wetland wastewater treatment design in cold climates. Ecol. Engin.e $19(1), 1-11$.

[33] Vymazal J., 2002. The use of sub-surface constructed wetlands for wastewater treatment in the Czech Republic: 10 years experience. Ecol. Engin., 18(5), 633-646.

[34] Yoo J.-H., Ro H.-M., Choi W.-J., Yoo S.-H., Han H.-K., 2006. Phosphorus adsorption and removal by sediments of a constructed marsh in Korea. Ecol. Engin., 27(2), 109117. 